\title{
PARTISIPASI MASYARAKAT DESA KOMODO DALAM PENGEMBANGAN EKOWISATA DI PULAU KOMODO
}

\author{
Rafael Modestus Ziku \\ E-mail: ziku.rafael@yahoo.com
}

\begin{abstract}
The purpose of this study was to examine the participation of community members of Komodo village with regard to ecotourism development in the island of Komodo, Komodo National Park, West Manggarai Regency. For the purpose of the study, qualitative research method was applied with the application of qualitative data collection techniques, including interviews, observation, and documentary analysis. Specifically, the study was conducted in the village of Komodo with active participation of 22 key informants. The results of this study revealed the roles of the community of Komodo village participation in ecotourism development, namely community members' participation in the program of Komodo Tourism Village of BNI (Bank Negara Indonesia), participation in ecotourism business, and participation in conservation. Factors that affect Komodo village community participation were divided into two main factors, such as factors that support and factor that hinder the community participation. The result also indicated the positive impact of the community participation on economic, environment, and social and cultural.
\end{abstract}

Keywords: Community participation, Komodo village Ecotourism development.

\section{Pendahuluan}

Pariwisata merupakan sektor andalan Kabupaten Manggarai Barat untuk memperoleh Pendapatan Asli Daerah (PAD). Kabupaten Manggarai Barat menyimpan potensi pariwisata yang tinggi apabila dibandingkan dengan kabupaten-kabupaten lainnya di Provinsi Nusa Tenggara Timur. Atraksiatraksi wisata alam dan budaya menyebar di seluruh Kabupaten Manggarai Barat (Iriyono, dkk., 2013).

Salah satu potensi wisata alam andalan Kabupaten Manggarai Barat adalah Taman Nasional Komodo (TNK). TNK merupakan aktivitas wisata utama di Kabupaten Manggarai Barat (Iriyono, dkk., 2013). Daya tarik utama 
TNK yaitu reptil raksasa purba biawak komodo (varanus komodoensis), tetapi keaslian dan kekhasan alamnya khususnya panorama savana dan panorama bawah laut merupakan daya tarik pendukung yang potensial (Renstra BTNK tahun 2010-2014).

Naga komodo merupakan kadal terbesar di dunia (Barnard, 2011). Wisatawan mulai mengunjungi pulau-pulau sejak ditemukannya naga komodo yang merupakan atraksi utama dari wilayah ini (Hitchcock, 1993 dalam Walpole dan Goodwin, 2001). Naga komodo khususnya menarik jumlah kunjungan yang besar terutama wisatawan dari negara-negara barat ke sebuah wilayah terpencil di Indonesia (Walpole dan Leader-Williams, 2002). Naga komodo merupakan aset terpenting dari TNK dan menjadi kebanggaan masyarakat Indonesia (Iriyono, dkk., 2013).

Pengelolaan kepariwisataan Taman Nasional Komodo (TNK) saat ini menggunakan pendekatan ekowisata. Aktifitas pariwisata TNK merupakan sebuah aktifitas ekowisata yang berhubungan dengan naga komodo dan keanekaragaman hayati di dalamnya. Potensi pariwisata dalam TNK faktanya sangat kompetitif dalam pemasaran global karena berhasil mendatangkan lebih dari 50.000 orang per tahun dan 85\% dari mereka adalah wisatawan asing (Iriyono, dkk., 2013).

Ekowisata merupakan suatu bentuk perjalanan wisata yang bertanggung jawab ke area-area alami yang dilakukan dengan tujuan konservasi lingkungan serta melestarikan kehidupan dan menyejahterakan penduduk setempat (The Ecotourism Society, 1990). Ekowisata merupakan sebuah aktivitas yang ramah lingkungan dan sanggup mendukung konservasi keanekaragaman hayati (Li, 2006 dalam Baksh, dkk., 2012)

Pengembangan ekowisata Taman Nasional Komodo (TNK) saat ini tidak lepas dari berbagai kendala. Permasalahan yang berkaitan dengan pemanfaatan jasa lingkungan dan wisata alam TNK seperti yang terangkum dalam Rencana Strategis Balai Taman Nasional Komodo 2010-2014, di antaranya adalah pemanfaatan kayu di kawasan oleh masyarakat untuk kayu bakar dan bahan baku cenderamata, belum maksimalnya Penerimaan Negara Bukan Pajak (PNBP) dari sektor ekowisata, dan masyarakat yang tinggal di sekitar kawasan TNK rata-rata merupakan masyarakat miskin yang menggantungkan hidupnya dari kekayaan sumberdaya alam hayati TNK.

Desa Komodo merupakan salah satu desa dalam kawasan Taman Nasional Komodo (TNK). Desa ini terletak di Pulau Komodo dan menjadi bagian dalam pengelolaan TNK. Desa ini berada dalam wilayah administrasi Kecamatan Komodo, Kabupaten Manggarai Barat. Desa Komodo sebagai desa yang berada di Pulau Komodo merupakan desa yang secara langsung merasakan dampak dari kegiatan ekowisata di Pulau Komodo. Mayoritas masyarakat Desa Komodo secara turun-temurun merupakan nelayan 
tradisional yang menggantungkan hidupnya dari hasil tangkapan laut TNK (Renstra BTNK 2010-2014). Sejalan dengan semakin berkembangnya ekowisata di Pulau Komodo, masyarakat Desa Komodo kini mulai beralih profesi ke sektor ekowisata.

Ekowisata merupakan sebuah bentuk pariwisata yang menekankan partisipasi masyarakat dalam pengembangannya (Epler Wood, 2002 dalam Baksh, dkk., 2012). Adapun masyarakat Desa Komodo saat ini telah berpartisipasi dalam pengembangan ekowisata di Pulau Komodo. Partisipasi masyarakat Desa Komodo dalam pengembangan ekowisata di Pulau Komodo tidak lepas dari berbagai faktor yang mempengaruhi masyarakat Desa Komodo itu sendiri. Berbagai bentuk partisipasi masyarakat Desa Komodo dalam pengembangan ekowisata di Pulau Komodo memberikan berbagai manfaat terhadap masyarakat Desa Komodo maupun terhadap lingkungan di Pulau Komodo.

Berdasarkan latar belakang yang telah diuraikan tersebut, artikel ini membahas mengenai bentuk-bentuk partisipasi masyarakat Desa Komodo dalam pengembangan ekowisata di Pulau Komodo, faktor-faktor yang mempengaruhi upaya partisipasi masyarakat Desa Komodo dalam pengembangan ekowisata di Pulau Komodo, serta dampak positif partisipasi masyarakat Desa Komodo dalam pengembangan ekowisata di Pulau Komodo.

Penelitian ini dilakukan di Desa Komodo, Taman Nasional Komodo, Kabupaten Manggarai Barat. Metode penelitian yang digunakan dalam artikel adalah metode penelitian dengan pendekatan kualitatif. Data dikumpulkan dengan menggunakan teknik observasi, wawancara, dan studi dokumen. Informan berjumlah 22 orang yang dipilih dengan teknik purposive. Data yang dikumpulkan dianalisis dengan teknik analisis deskriptif kualitatif.

\section{Partisipasi Masyarakat dalam Pengembangan Ekowisata}

Partisipasi masyarakat adalah keterlibatan masyarakat sesuai dengan hak dan kewajibannya sebagai subyek dan obyek pembangunan, keterlibatan dalam tahap pembangunan ini dimulai sejak tahap perencanaan sampai dengan pengawasan berikut segala hak dan tanggungjawabnya (Kamus Tata Ruang, 1998:79). Pendekatan partisipasi masyarakat telah dianjurkan sebagai sebuah bagian utuh pembangunan pariwisata berkelanjutan (Okazaki, 2008). Ekowisata selalu menekankan partisipasi masyarakat lokal dalam pengelolaannya. Fungsi-fungsi utama ekowisata adalah perlindungan wilayah-wilayah alami, penciptaan keuntungan, pendidikan dan partisipasi masyarakat lokal dan pembangunan masyarakat (Ross dan Wall, 1999). Ekowisata harus melibatkan masyarakat lokal, menyalurkan keuntungan ekonomi bagi perlindungan lingkungan setempat, dan berkontribusi bagi pemeliharaan keanekaragaman spesies-spesies lokal dengan meminimalisir 
dampak pengunjung serta mempromosikan pendidikan bagi wisatawan (Hill dan Hill, 2011).

Keith Davis dalam Sastropoetro (1988:16), bentuk-bentuk partisipasi meliputi: 1). konsultasi, biasanya dalam bentuk jasa; 2). sumbangan spontan berupa uang dan barang; 3). mendirikan proyek yang sifatnya berdikari dan donornya berasal dari pihak ketiga; 4). mendirikan proyek yang sifatnya berdikari dan dibiayai seluruhnya oleh masyarakat; 5). sumbangan dalam bentuk kerja; 6). aksi massa; 7). mengadakan pembangunan di kalangan keluarga; dan 8). membangun proyek masyarakat yang bersifat otonom. Adapun jenis-jenis partisipasinya meliputi: 1). pikiran; 2). tenaga; 3). pikiran dan tenaga; 4). keahlian; 5). barang; dan 6). uang.

\section{Faktor-Faktor yang Mempengaruhi Partisipasi Masyarakat}

Faktor-faktor yang mempengaruhi partisipasi masyarakat dikategorikan ke dalam dua jenis, yaitu faktor yang mendorong dan faktor yang menghambat. Penelitian Wang, Pfister dan Morais (2006) menemukan bahwa masyarakat lokal yang menyadari akan potensi manfaat dari pariwisata adalah faktor yang mempengaruhi mereka dalam meningkatkan partisipasi dalam pariwisata.

Tosun (2000) mengidentifikasi tiga hal utama yang menghambat masyarakat untuk berpartisipasi dalam proses pembangunan pariwisata dalam konteks negara berkembang, yaitu: 1). Keterbatasan operasional (operational limitations), yang meliputi pemusatan administrasi publik dalam bidang pariwisata, kurangnya koordinasi, dan kurangnya informasi; 2). Keterbatasan struktural (structural limitations), diantaranya attitudes of professionals, kurangnya keahlian, dominasi elit, kurangnya peraturan yang sesuai, kurangnya sumber daya manusia terlatih, tingginya biaya partisipasi masyarakat, dan kurangnya sumber-sumber pendanaan; 3). Keterbatasan kebudayaan (cultural limitations), meliputi: kapasitas yang terbatas dalam masyarakat miskin, dan sikap apatis dan tingkat kesadaran yang rendah dalam komunitas lokal.

\section{Manfaat Partisipasi Masyarakat dalam Pengembangan Ekowisata}

Partisipasi masyarakat dalam pengembangan pariwisata adalah perlu apabila mereka diberikan pembagian keuntungan yang adil bagi ekonomi lokal (Aref dan Ma'arof, 2008). Beberapa manfaat ekonomi yang komunitas lokal dapat peroleh dari ekowisata adalah peluang kerja, pembangunan yang berhubungan dengan infrastruktur (seperti jaringan jalan yang lebih baik dan air) dan usaha ekowisata (Ezebilo, dkk., 2010). Fakta bahwa orang asing bepergian jauh untuk mengunjungi sebuah komunitas dan masyarakat lokal mendapatkan keuntungan darihal tersebut dapatmeningkatkan penghargaan masyarakat terhadap sumber daya alami mereka. Rasa kebanggaan ini 
membuat anggota masyarakat tersebut mengkonservasi lingkungan mereka (Scheyvens, 2002). Partisipasi masyarakat dalam pengembangan ekowisata berdampak positif terhadap terpeliharanya lingkungan dimana ekowisata tersebut diselenggarakan. Partisipasi masyarakat dalam ekowisata dapat membuat sebuah promosi yang positif bagi perlindungan lingkungan ekowisata (Bansal dan Kumar, 2013).

Santosa dan Heroepoetri (2005: 5) merangkum manfaat dari partisipasi masyarakat, yaitu sebagai berikut: 1). menuju masyarakat yang lebih bertanggung jawab; 2). meningkatkan proses belajar; 3). mengeliminir perasaan terasing; 4). menimbulkan dukungan dan penerimaan dari rencana pemerintah; 5). menciptakan kesadaran politik; 6). keputusan dari hasil partisipasi mencerminkan kebutuhan dan keinginan masyarakat; 7). menjadi sumber dari informasi yang berguna, dan ; 8). merupakan komitmen sistem demokrasi.

\section{Bentuk-Bentuk Partisipasi Masyarakat Desa Komodo dalam Pengem- bangan Ekowisata}

Masyarakat Desa Komodo berpartisipasi dalam pengembangan ekowisata di Pulau Komodo. Mayoritas masyarakat Desa Komodo yang secara turuntemurun merupakan nelayan tradisional yang menggantungkan hidupnya dari hasil tangkapan laut, namun sejalan dengan semakin berkembangnya ekowisata di Pulau Komodo, masyarakat Desa Komodo kini mulai beralih profesi ke sektor ekowisata. Partisipasi masyarakat Desa Komodo dalam pengembangan ekowisata tidak lepas dari campur tangan berbagai pihak pemangku kepentingan (stakeholders) baik dari unsur pemerintah maupun swasta, seperti Balai Taman Nasional Komodo, Bank Negara Indonesia, dan Yayasan Komodo Kita. Masing-masing stakeholders mempunyai peran dalam menunjang partisipasi masyarakat Desa Komodo, seperti dengan cara memberikan pelatihan pengembangan sumber daya manusia, bantuan permodalan serta bantuan peralatan.

Pada bulan Februari 2013, Desa Komodo diresmikan sebagai Desa Wisata Komodo Bank Negara Indonesia (BNI). Program Desa Wisata Komodo disponsori oleh BNI dengan dibantu oleh Yayasan Komodo Kita (YKK). Dalam konsep desa wisata, peran aktif pembangunan dan pengelolaan desa wisata berada di tangan masyarakat desa (Putra dan Pitana, 2010: 70). Konsep desa wisata mengindikasikan tentang pentingnya keterlibatan masyarakat dalam pengembangan Desa Wisata. Masyarakat Desa Komodo sebagai masyarakat penyelenggara ekowisata di Pulau Komodo berpartisipasi dalam program Desa Wisata Komodo BNI. Bentuk-bentuk partisipasi masyarakat, diantaranya adalah dengan memberikan usulan serta menjadi pekerja pembangunan infrastruktur desa (Foto 1). 


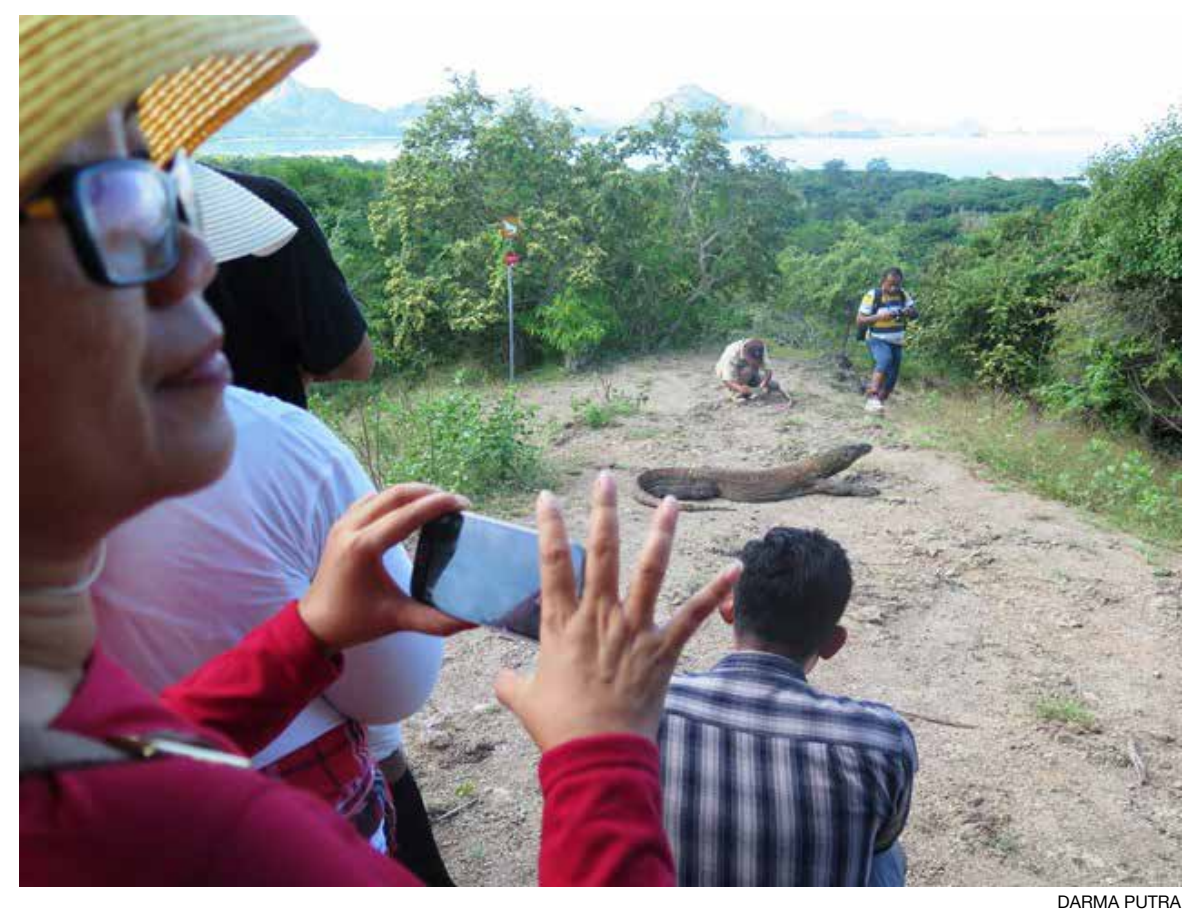

Foto 1. Wisatawan menyaksikan komodo di Pulau Komodo.

Partisipasi dapat didefinisikan sebagai keterlibatan mental atau pikiran dan emosi atau perasaan seseorang di dalam situasi kelompok yang mendorongnya untuk memberikan sumbangan kepada kelompok dalam usaha mencapai tujuan serta turut bertanggung jawab terhadap usaha yang bersangkutan (Davis dalam Sastropoetro, 1988: 13). Masyarakat Desa Komodo berpartisipasi dalam program Desa Wisata Komodo BNI, yaitu dengan memberikan usulan. Usulan masyarakat Desa Komodo diantaranya adalah agar dalam pembangunan jalan pantai tidak menghambat pergerakan masyarakat serta agar Yayasan Komodo Kita membangun MCK pada tiap-tiap rumah masyarakat. Usulan masyarakat merupakan hal yang menjadi pertimbangan dalam proses pengambilan keputusan suatu proyek pembangunan. Bentuk patisipasi masyarakat Desa Komodo dengan memberikan usulan dalam program Desa Wisata Komodo BNI apabila dikaitkan dengan tipologi partisipasi masyarakat menurut Jules Pretty termasuk dalam karakter partisipasi konsultatif, dimana menurut Pretty (1995) partisipasi konsulatif yaitu dimana masyarakat berpartisipasi dengan cara berkonsultasi, melakukan dengar pendapat, sedangkan orang luar mendengarkan, menganalisis masalah dan pemecahannya. Masyarakat Desa Komodo berkonsultasi dan melakukan dengar pendapat dalam bentuk memberikan usulan, sedangkan pihak luar, dalam hal ini adalah pihak Yayasan Komodo Kita, mendengarkan usulan dan saran masyarakat Desa 
Komodo tersebut.

Partisipasi dalam tahap pelaksanaan adalah pelibatan seseorang pada tahap pelaksanaan pekerjaan suatu proyek. Masyarakat dapat memberikan tenaga, uang ataupun material/barang serta ide-ide sebagai salah satu wujud partisipasinya pada pekerjaan tersebut (Ericson dalam Slamet,1993: 89). Masyarakat Desa Komodo berpartisipasi dalam program Desa Wisata Komodo BNI sebagai pekerja proyek pembangunan infrastruktur desa. Pengembangan Desa Wisata Komodo BNI diawali dengan pembangunan berbagai infrastruktur di Desa Komodo. Berbagai infrastruktur desa yang dibangun berupa pembangunan jalan desa dengan paving block, saluran pembuangan air desa, pengembangan sarana Mandi Cuci Kakus (MCK) komunal, serta pembangunan jalan pantai. Dalam membangun berbagai infrastruktur desa tersebut, Yayasan Komodo Kita menggunakan pekerja baik pekerja yang didatangkan dari luar Desa Komodo maupun pekerja dari masyarakat Desa Komodo sendiri. Masyarakat Desa Komodo berpartisipasi dengan menjadi pekerja proyek pembangunan infrastruktur desa, seperti proyek pembangunan jalan setapak, jalan pantai dan MCK. Dengan memberikan kesempatan bagi masyarakat untuk mengambil bagian dalam setiap proses pengambilan keputusan yang menyangkut nasib mereka, maka masyarakat akan merasa menjadi bagian dari proses sehingga tumbuh rasa memiliki dan pada gilirannya bisa memperoleh manfaat atas perubahan yang terjadi di sekitar mereka (Hadi, 2001:48). Saat ini masyarakat Desa Komodo sudah menikmati berbagai infrastruktur yang melibatkan mereka dalam pengerjaannya.

Undang-Undang 10/2009 tentang Kepariwisataan menjelaskan bahwa usaha pariwisata adalah usaha yang menyediakan barang dan / atau jasa bagi pemenuhan kebutuhan wisatawan dan penyelenggaraan pariwisata. Usaha pariwisata tentunya menyediakan produk yang ditawarkan kepada wisatawan yaitu barang dan jasa. Produk wisata itu sendiri diklasifikasi dalam dua jenis, yaitu produk yang nyata (tangible) maupun produk wisata yang tidak berbentuk (intangible). Adapun partisipasi masyarakat Desa Komodo dalam usaha ekowisata di Pulau Komodo menghasilkan produk yang nyata maupun produk yang tidak berbentuk. Bentuk-bentuk partisipasi masyarakat Desa Komodo dalam usaha ekowisata di Pulau Komodo diantaranya sebagai pengerajin patung komodo, menjual cenderamata,sebagai pemandu wisata alam (naturalist guide), mengelola homestay, dan menyewakan perahu motor

Salah satu bentuk partisipasi masyarakat Desa Komodo dalam usaha ekowisata adalah dengan menjadi pengerajin patung komodo. Para pengerajin patung komodo di Desa Komodo bergabung dalam sebuah kelompok yang dinamakan kelompok Gunung Ara, saat ini terdapat 34 anggota yang tergabung dalam kelompok tersebut. Kecendrungan wisatawan untuk 


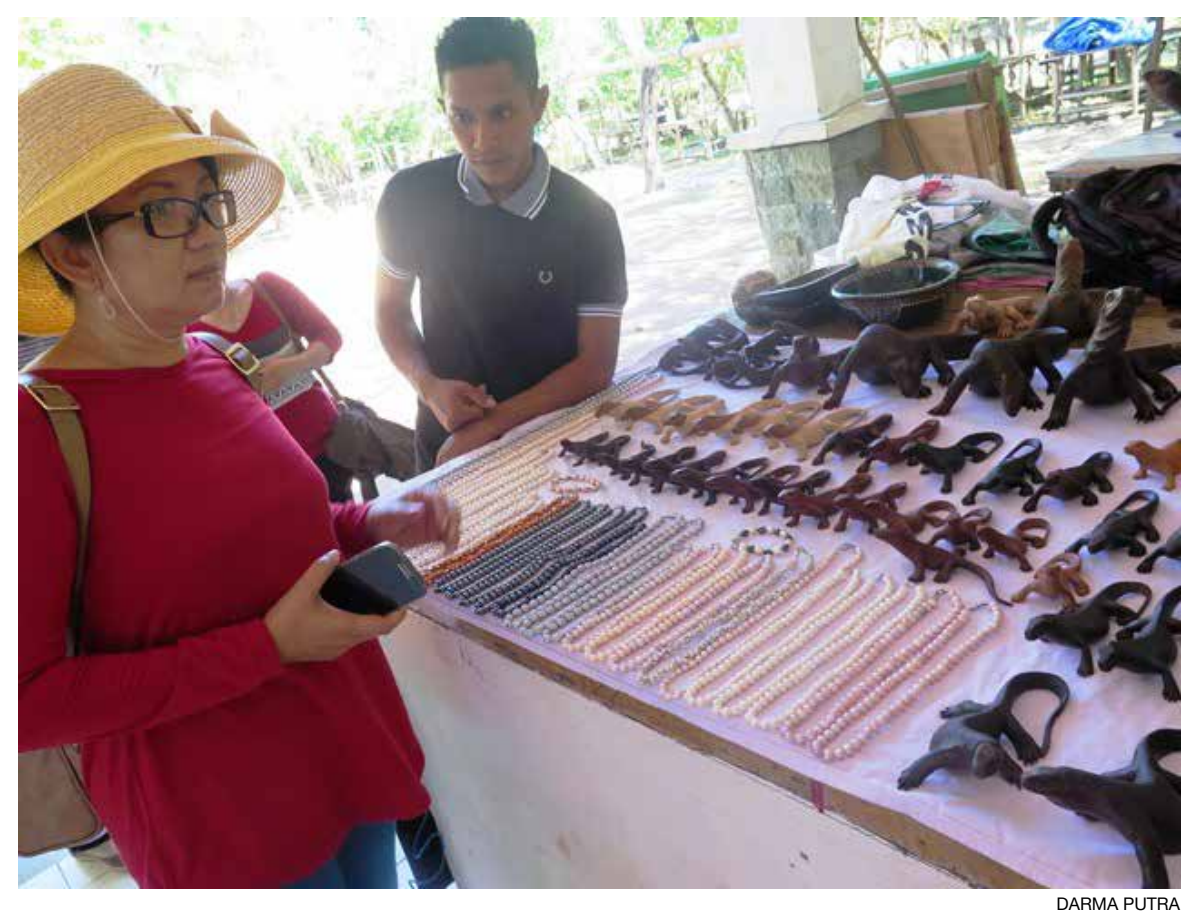

Foto 2. Warga Komodo menjual suvenir di Pulau Komodo.

memiliki oleh-oleh khas dari suatu daerah yang mereka kunjungi membuka peluang bagi masyarakat setempat untuk menyediakan cenderamata khas, seperti patung komodo untuk dijual kepada wisatawan yang mengunjungi Pulau Komodo.

Selain menjadi pengerajin patung komodo, bentuk lain partisipasi masyarakat Desa Komodo dalam usaha ekowisata di Pulau Komodo adalah dengan menjual cenderamata (Lihat Foto 2). Para penjual cenderamata menjual barang-barangnya di art shop yang telah disediakan oleh Balai Taman Nasional Komodo di Loh Liang dan di art shop yang berada di Desa Komodo. Selain itu, terdapat penjual cenderamata yang berinisiatif untuk mencari pembeli dengan menggunakan perahu motor ke tempat-tempat dimana wisatawan berada di sekitar Pulau Komodo, misalnya di pantai merah (pink beach). Hal ini merupakan tindakan yang tidak diperkenankan karena berpotensi mengganggu kenyamanan wisatawan.

Menjadi pemandu wisata alam (naturalist guide) merupakan salah satu bentuk partisipasi masyarakat Desa Komodo dalam usaha ekowisata di Pulau Komodo. Masyarakat Desa Komodo yang bekerja sebagai naturalist guide menghasilkan produk ekowisata yang tidak berbentuk, yaitu berupa pelayanan (service) bagi wisatawan yang mengunjungi Pulau Komodo, khususnya di Loh Liang. Saat ini terdapat sembilan orang masyarakat Desa Komodo yang menjadi naturalist guide. Tugas dari naturalist guide adalah 
memandu wisatawan yang ingin menyaksikan hewan komodo. Menjadi naturalist guide di Taman Nasional Komodo umumnya ataupun di Pulau Komodo khususnya membutuhkan keterampilan dalam menghadapi hewan komodo, mengingat hewan komodo merupakan jenis hewan pemakan daging (karnivora), hewan ini berpotensi menyerang manusia yang berada di dekatnya. Naturalist guide bertanggung jawab terhadap keselamatan wisatawan.

Bentuk lain partisipasi masyarakat Desa Komodo dalam usaha ekowisata di Pulau Komodo adalah dengan mengelola homestay. Dengan mengelola homestay, artinya masyarakat Desa Komodo berperan serta dalam usaha ekowisata dengan menyediakan produk ekowisata yang tidak berwujud (intangible). Homestay merupakan sebuah jenis akomodasi berupa rumahrumah pribadi, dimana para pengunjung atau tamu membayar secara langsung atau tidak langsung kepada pemilik rumah, dimana interaksi terjadi secara intensif karena terdapat bagian-bagian rumah yang digunakan secara bersama antara tamu dan tuan rumah (Lynch 2003; Sweeney 2008:20; Lama, 2013:11). Dari definisi tersebut dapat dilihat signifikansi peran serta tuan rumah dalam pengelolaan sebuah homestay. Masyarakat Desa Komodo sebagai masyarakat penyelenggara ekowisata di Pulau Komodo berperan serta dalam pengelolaan homestay. Pengelolaan homestay oleh masyarakat tidak lepas dari campur tangan Yayasan Komodo Kita (YKK). YKK memberikan bantuan berupa tempat tidur bagi masyarakat Desa Komodo yang mengelola homestay di rumahnya.

Bentuk lain partisipasi masyarakat Desa komodo dalam usaha ekowisata di Pulau Komodo adalah dengan menyewakan perahu motor. Lokasi Pulau Komodo yang dikelilingi lautan membuat transportasi laut menjadi transportasi utama di wilayah ini. Kapal motor maupun perahu motor merupakan sarana transportasi yang umum digunakan oleh masyarakat umum ataupun wisatawan yang datang atau pergi dari Pulau Komodo. Masyarakat Desa Komodo yang merupakan nelayan tradisional, memiliki perahu motor untuk menangkap ikan. Perahu motor tersebut juga digunakan untuk memperoleh pemasukan, dengan cara menyewakannya kepada kapal-kapal motor besar yang hendak menurunkan wisatawan ke pantai di sekitar Pulau Komodo, seperti di Pantai Merah atau Pink Beach. Penyewaan perahu motor yang dilakukan oleh masyarakat tersebut secara tidak langsung berkontribusi terhadap terjaganya ekosistem lautan di wilayah perairan Pulau Komodo. Dengan memanfaatan perahu milik masyarakat untuk menurunkan penumpangnya, berarti kapal-kapal motor tidak perlu menurunkan jangkarnya ke laut yang berpotensi merusak ekosistem bawah laut.

Partisipasi adalah kerja sama antara rakyat dan pemerintah dalam merencanakan, melaksanakan, melestarikan dan mengembangkan hasil 
pembangunan (Soetrisno, 1995: 207). Terdapat dua unsur penting dalam partisipasi, yaitu unsur pemerintah dan masyarakat. Dalam kaitannya dengan partisipasi masyarakat Desa Komodo dalam konservasi, pihak pemerintah melalui Balai Taman Nasional Komodo (BTNK) bekerja sama dengan masyarakat Desa Komodo dalam konservasi lingkungan di Pulau Komodo. Bentuk partisipasi masyarakat Desa Komodo dalam konservasi lingkungan, salah satunya adalah dengan bergabung dalam sebuah kelompok pemberdayaan masyarakat yang dinamakan kelompok Masyarakat Mitra Polisi Kehutanan (MMP).

Definisi dari MMP seperti yang terangkum dalam Peraturan Menteri Kehutanan Republik Indonesia tentang Masyarakat Mitra Polisi Kehutanan, Bab I, Pasal 1 ayat 4, adalah kelompok masyarakat sekitar hutan yang membantu Polhut dalam pelaksanaan perlindungan hutan di bawah koordinasi, pembinaan dan pengawasan instansi pembina. Umumnya, masyarakat yang diberdayakan sebagai MMP adalah masyarakat yang berada di sekitar hutan atau kawasan lindung. BTNK memberdayakan masyarakat Desa Komodo untuk menjaga lingkungan di Pulau Komodo. Saat ini terdapat 10 orang masyarakat Desa Komodo yang diberdayakan sebagai MMP. BTNK memberikan pembinaan kepada MMP setiap tahunnya secara berkala. Tugas dari MMP Desa Komodo adalah melakukan pengamanan darat dan laut, serta memberikan pemahaman bagi masyarakat baik dalam kawasan atau luar yang berhubungan dengan zonasi. Keuntungan memberdayakan masyarakat Desa Komodo sebagai MMP adalah karena mereka merupakan masyarakat lokal, sehingga arahan yang mereka berikan mudah dipahami oleh masyarakat di sekitarnya. Masyarakat Desa Komodo yang diberdayakan sebagai MMP mendapatkan gaji tiap bulannya dari BTNK.

Bentuk lain partisipasi masyarakat Desa Komodo dalam konservasi Pulau Komodo selain Masyarakat Mitra Polisi Kehutanan adalah dengan menjadi bagian dalam Kader Konservasi. Kader konservasi adalah seseorang yang telah diberikan pendidikan atau yang telah ditetapkan sebagai penerus upaya konservasi Sumber Daya Alam (SDA) yang memiliki kesadaran maupun ilmu pengetahuan mengenai SDA, serta secara sukarela, bersedia dan mampu menyampaikan pesan konservasi kepada masyarakat di sekitarnya. Pihak pemerintah melalui Balai Taman Nasional Komodo (BTNK) memberdayakan masyarakat Desa Komodo sebagai Kader Konservasi. BTNK membentuk dan memberikan pembinaan yang berkaitan dengan konservasi lingkungan kepada Kader Konservasi secara berkala. Dari pengetahuan yang diperoleh dari BTNK, diharapkan Kader Konservasi menjadi pelopor dan penggerak upaya-upaya konservasi sumber daya alam hayati dan ekosistemnya dan mampu berperan aktif dalam menumbuhkan upayaupaya konservasi sumber daya alam kawasan Taman Nasional Komodo umumnya dan di Pulau Komodo khususnya kepada masyarakat umum. 


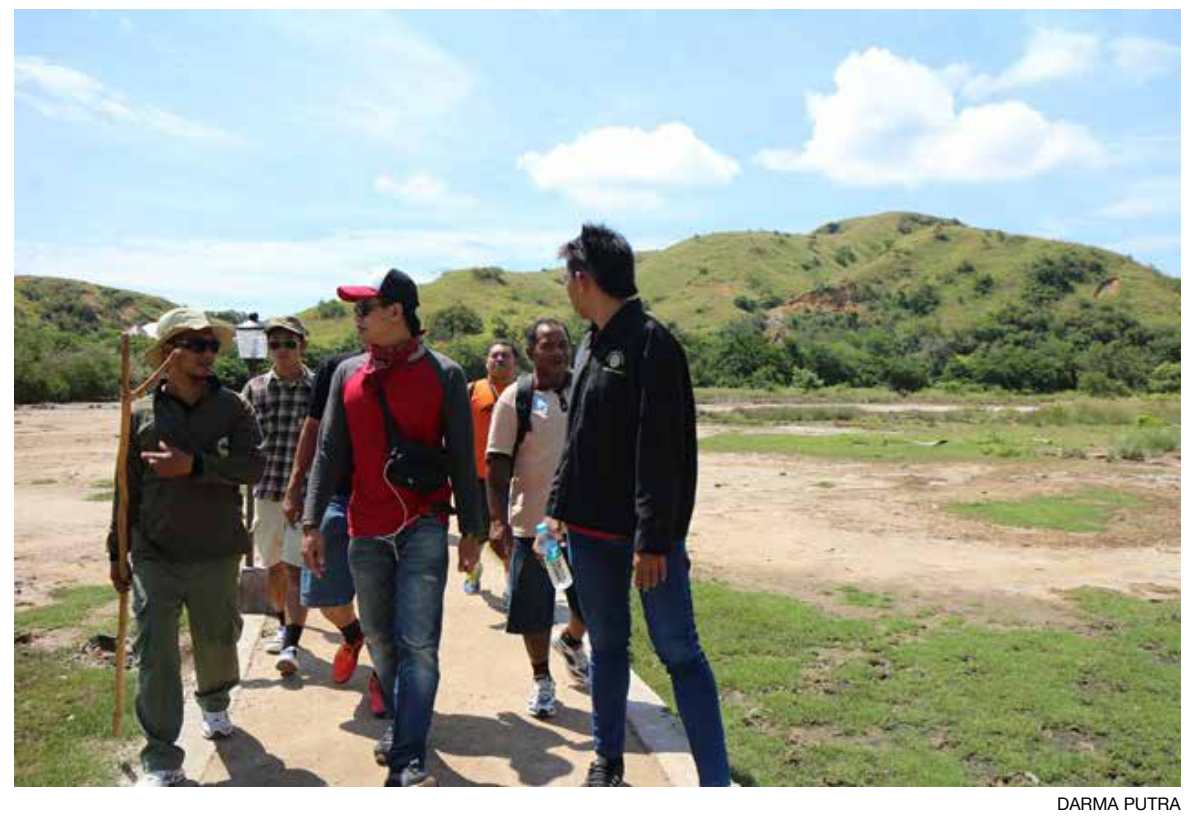

Foto 3. Warga lokal menjadi ranger atau pemandu wisata Komodo di Pulau Long Liah

Keuntungan memberdayakan masyarakat lokal sebagai Kader Konservasi di Pulau Komodo, adalah karena mudah dipahami oleh masyarakat umum di sekelilingnya. Terdapat 43 masyarakat Desa Komodo yang menjadi bagian dari Kader Konservasi, yang terdiri dari laki-laki dan perempuan. Kader Konservasi dari Desa Komodo bekerja secara suka rela, tanpa dibayar (Foto 3).

\section{Faktor-faktor yang Mempengaruhi Partisipasi Masyarakat Desa Komodo dalam Pengembangan Ekowisata}

Partisipasi masyarakat Desa Komodo dalam pengembangan ekowisata di Pulau Komodo tidak lepas dari berbagai faktor yang mempengaruhi masyarakat Desa Komodo itu sendiri. Faktor-faktor yang mempengaruhi masyarakat Desa Komodo terbagi ke dalam dua jenis, yaitu faktor-faktor yang mendorong dan faktor-faktor yang menghambat.

Faktor-faktor yang mendorong partisipasi masyarakat Desa Komodo dalam pengembangan ekowisata di Pulau Komodo, salah satunya adalah karena adanya dukungan dari pihak-pihak pemangku kepentingan (stakeholders). Partisipasi masyarakat Desa Komodo dalam pengembangan ekowisata di Pulau Komodo tidak lepas dari campur tangan berbagai stakeholders. Stakeholders yang terlibat dalam pengembangan ekowisata berasal dari unsur pemerintah maupun swasta, seperti Balai Taman Nasional Komodo dan Yayasan Komodo Kita. Masing-masing stakeholders mempunyai peran dalam mendukung partisipasi masyarakat Desa Komodo, 
seperti dengan cara memberikan pelatihan pengembangan sumber daya manusia, bantuan permodalan maupun bantuan peralatan bagi masyarakat Desa Komodo yang berpartisipasi dalam pengembangan ekowisata. Berbagai dukungan stakeholders tersebut memberikan dorongan bagi masyarakat Desa Komodo untuk berpartisipasi dalam pengembangan ekowisata di Pulau Komodo.

Selain karena adanya dukungan dari stakeholders, faktor lain yang mendorong masyarakat Desa Komodo untuk berpartisipasi dalam pengembangan ekowisata di Pulau Komodo adalah karena adanya motivasi masyarakat Desa Komodo untuk memperoleh manfaat ekonomi dari ekowisata. Menurut Abraham Maslow, kebutuhan fisiologis merupakan hirarki kebutuhan manusia yang paling dasar yang terkait dengan pemenuhan kebutuhan ekonomi, seperti sandang, pangan dan papan. Didorong oleh kebutuhan akan pemenuhan kebutuhan fisiologis tersebut, masyarakat Desa Komodo berpartisipasi dalam pengembangan ekowisata di Pulau Komodo. Masyarakat Desa Komodo yang berpartisipasi dalam pengembangan ekowisata mendapatkan keuntungan ekonomi. Keuntungan tersebut digunakan untuk menghidupi diri sendiri, keluarga maupun membiayai anak-anak bersekolah.

Adanya motivasi untuk menjaga lingkungan merupakan salah satu faktor yang mendorong masyarakat Desa Komodo untuk berpartisipasi dalam pengembangan ekowisata. Masyarakat lokal yang menyadari akan potensi manfaat dari pariwisata adalah faktor yang mempengaruhi mereka meningkatkan partisipasi dalam pariwisata (Wang, Pfister dan Morais, 2006). Kegiatan pariwisata berpotensi memberi manfaat terhadap terjaganya lingkungan. Masyarakat Desa Komodo sebagai masyarakat penyelenggara ekowisata di Pulau Komodo berpartisipasi dalam pengembangan ekowisata, karena mereka menyadari akan manfaat dari adanya kegiatan ekowisata di wilayah mereka. Manfaat tersebut yaitu dapat mengkonservasi lingkungan di Pulau Komodo. Hal tersebut mendorong mereka untuk berpartisipasi dalam pengembangan ekowisata. Masyarakat Desa Komodo berpartisipasi menjaga lingkungan dengan terlibat dalam kelompok Masyarakat Mitra Polisi Kehutanan dan Kader Konservasi. Adapun pemandangan lingkungan Pulau Komodo yang indah.

Faktor yang menghambat partisipasi masyarakat Desa Komodo dalam pengembangan ekowisata di Pulau Komodo, diantaranya adalah terbatasnya anggaran. Anggaran yang memadai sangat dibutuhkan dalam setiap upaya partisipasi masyarakat dalam pembangunan pariwisata. Untuk berpartisipasi dalam kegiatan pengembangan ekowisata di Pulau Komodo tentunya membutuhkan anggaran. Namun, masyarakat yang tinggal di kawasan Taman Nasional Komodo (TNK) rata-rata masyarakat miskin yang menggantungkan hidupnya dari kekayaan sumberdaya alam hayati TNK 
(Renstra BTNK 2010-2014). Masyarakat dalam kawasan TNK umumnya dan di Pulau Komodo khususnya yang rata-rata merupakan masyarakat miskin, kesulitan untuk berpartisipasi dalam pengembangan ekowisata karena keterbatasan anggaran. Sebagian besar pengelola kawasan taman nasional cenderung kekurangan dana untuk mengantisipasi perkembangan permintaan industri pariwisata dan tuntutan konservasi, sedangkan pemerintah sebagai pengelola kawasan tersebut tidak memberikan dana yang layak bagi taman nasional (Nurdin, 2008).

Balai Taman Nasional Komodo (BTNK) sebagai pengelola kawasan TNK memiliki keterbatasan anggaran. Program pengembangan kualitas SDM masyarakat dalam kawasan TNK yang diprakarsai oleh BTNK tidak diberikan secara merata kepada semua masyarakat akibat masalah keterbatasan anggaran ini. Selain itu, keterbatasan anggaran menyebabkan BTNK membatasi jumlah penerima bantuan permodalan dan peralatan bagi masyarakat yang berpartisipasi dalam pengembangan ekowisata. Keterbatasan anggaran pengelolaan BTNK berdampak pada terhambatnya partisipasi masyarakat Desa Komodo dalam pengembangan ekowisata.

Selain karena adanya keterbatasan anggaran, sikap apatis dan kesadaran masyarakat yang rendah menjadi faktor lain yang menghambat partisipasi masyarakat Desa Komodo dalam pengembangan ekowisata. Masyarakat cenderung berpartisipasi hanya apabila didorong untuk melakukannya, dan seringkali mereka tidak terdorong (Rosener, 1982 dalam Tosun, 1999). Pelatihan guide yang dipelopori oleh Balai Taman Nasional Komodo (BTNK) merupakan upaya untuk meningkatkan kualitas sumber daya manusia masyarakat setempat, agar dapat berpartisipasi dalam pengembangan ekowisata di Pulau Komodo. Namun, terdapat masyarakat Desa Komodo tidak mempunyai inisiatif untuk mengembangkan pelatihan yang telah diselenggarakan oleh BTNK tersebut.

Fluktuasi kunjungan wisatawan ke Pulau Komodo merupakan salah satu faktor penghambat partisipasi masyarakat Desa Komodo dalam pengembangan ekowisata. Fluktuasi kunjungan wisatawan merupakan suatu keadaan dimana terjadi ketidakmenentuannya jumlah kunjungan wisatawan yang mengunjungi suatu destinasi wisata. Pulau Komodo sebagai destinasi ekowisata mengalami fluktuasi kunjungan wisatawan. Tingkat kunjungan wisatawan yang melimpah (high season) ke Pulau Komodo adalah pada bulan Juli sampai November dan ketika berlabuhnya kapal pesiar yang mengangkut ratusan wisatawan. Namun, ketika low season atau ketika kapal pesiar tidak mengunjungi Pulau Komodo, masyarakat Desa Komodo yang berpartisipasi dalam usaha ekowisata, seperti pengerajin patung komodo, penjual cenderamata atau pemandu wisata alam (naturalist guide), kesulitan dalam menjual produk ekowisata, karena sedikitnya jumlah wisatawan yang membeli barang atau jasa yang mereka tawarkan. 
Setiap usaha atau bisnis tentunya memiliki produk yang ditawarkan bagi konsumen atau pembeli. Usaha ekowisata juga memiliki produk berupa barang atau jasa yang ditawarkan kepada wisatawan. Namun, produk yang ditawarkan pelaku usaha ekowisata tidak akan sampai kepada wisatawan apabila terdapat kesulitan dalam hal pemasaran. Kesulitan memasarkan produk ekowisata dialami oleh masyarakat Desa Komodo yang berpartisipasi dalam usaha ekowisata. Masyarakat Desa Komodo berpartisipasi dalam usaha ekowisata sebagai pengerajin patung komodo, penjual cenderamata, naturalist guide, mengelola homestay, dan menyewakan perahu motor. Namun, masyarakat mengalami kesulitan dalam hal memasarkan produkproduk tersebut. Kesulitan dalam memasarkan produk ekowisata merupakan salah satu faktor penghambat partisipasi masyarakat Desa Komodo dalam usaha ekowisata di Pulau Komodo.

\section{Dampak Partisipasi Masyarakat Desa Komodo dalam Pengem- bangan Ekowisata}

Partisipasi masyarakat dalam pengembangan ekowisata memberikan dampak positif, baik bagi masyarakat itu sendiri maupun bagi lingkungan di mana ekowisata diselenggarakan. Adapun dampak positif dari partisipasi masyarakat Desa Komodo dalam pengembangan ekowisata di Pulau Komodo meliputi sektor ekonomi, lingkungan dan sosial budaya.

Partisipasi masyarakat dalam pengembangan ekowisata memberikan dampak positif terhadap perekonomian masyarakat itu sendiri. Dampak positif partisipasi masyarakat Desa Komodo dalam pengembangan ekowisata di Pulau Komodo terhadap perekonomian, terindikasi dengan adanya pendapatan dari usaha ekowisata. Pengeluaran dari wisatawan secara langsung ataupun tidak langsung merupakan sumber pendapatan dari beberapa perusahaan, organisasi, atau masyarakat perorangan yang melakukan usaha di sektor pariwisata (Pitana dan Diarta, 2009:186). Partisipasi masyarakat dalam usaha ekowisata memberikan peluang bagi masyarakat itu sendiri untuk memperoleh pendapatan. Masyarakat Desa Komodo berpartisipasi dalam usaha ekowisata sebagai pengerajin patung komodo, penjual cenderamata, pemandu wisata alam (naturalist guide), mengelola homestay, dan menyewakan perahu motor. Dari usaha-usaha tersebut, masyarakat Desa Komodo memperoleh pendapatan.

Salah satu dampak positif partisipasi masyarakat dalam pengembangan ekowisata adalah terbukannya peluang kerja baru bagi masyarakat Desa Komodo itu sendiri. Masyarakat Desa Komodo merupakan masyarakat dengan kebudayaan yang dibangun dari aspek kelautan, di mana laut merupakan sumber daya alam tempat menggantungkan hidup. Namun, dengan semakin berkembangnya ekowisata di Pulau Komodo, membuat peluang bagi masyarakat Desa Komodo untuk berpartisipasi dalam usaha 
ekowisata semakin terbuka. Masyarakat Desa Komodo yang awalnya merupakan nelayan, secara perlahan beralih profesi dengan berpartisipasi di sektor usaha ekowisata. Terdapat masyarakat desa yang awalnya nelayan karena tidak mempunyai kemampuan lain, kini dapat bekerja pada bidang ekowisata di pulau Komodo.

Selain berdampak positif terhadap perekonomian, partisipasi masyarakat Desa Komodo dalam pengembangan ekowisata di Pulau Komodo juga berdampak positif terhadap lingkungan. Indikator dampak positif partisipasi masyarakat Desa Komodo terhadap lingkungan, salah satunya adalah terpeliharanya ekosistem darat dan laut di Pulau Komodo. Partisipasi masyarakat memberikan sebuah dorongan yang kuat bagi perlindungan sumber daya area pariwisata (Wang dan Tong, 2009). Adapun partisipasi masyarakat Desa Komodo dalam pengembangan ekowisata di Pulau Komodo berdampak positif terhadap terpeliharanya ekosistem darat dan laut di sekitar Pulau Komodo. Masyarakat Desa Komodo berperan serta secara aktif dalam konservasi lingkungan dengan menjadi bagian dari Masyarakat Mitra Polisi Kehutanan dan Kader Konservasi. Mayoritas masyarakat Desa Komodo berprofesi sebagai nelayan yang menggantungkan hidupnya dari hasil tangkapan yang mereka peroleh dari lautan. Interaksi tinggi masyarakat Desa Komodo terhadap lautan berpotensi mengurangi bahkan merusak ekosistem lautan di sekitar Pulau Komodo. Hal ini merupakan sebuah ancaman bagi keberlanjutan kawasan perairan Taman Nasional Komodo umumnya dan Pulau Komodo khususnya.

Dengan semakin berkembangnya ekowisata di Pulau Komodo, menarik minat masyarakat setempat untuk mengais rejeki dari sektor ekowisata. Masyarakat Desa Komodo yang awalnya merupakan nelayan, memilih untuk beralih profesi bekerja pada sektor ekowisata, seperti menjadi pengerajin patung komodo, menjual cenderamata, sebagai pemandu wisata alam (naturalist guide), mengelola homestay, serta menyewakan perahu motor. Peralihan profesi ini menyebabkan jumlah nelayan yang berasal dari Desa Komodo semakin berkurang. Dengan berkurangnya jumlah nelayan, maka semakin kecil potensi negatif kerusakan ekositem laut yang dapat ditimbulkan oleh aktivitas penangkapan ikan, sehingga menyebabkan ekosistem laut di sekitar Pulau Komodo lebih terpelihara.

Selain memberikan dampak positif terhadap terpeliharanya ekosistem darat dan laut di Pulau Komodo, partisipasi masyarakat Desa Komodo dalam pengembangan ekowisata juga berdampak positif terhadap bertambahnya pengetahuan masyarakat mengenai lingkungan. Masyarakat Mitra Polisi Kehutanan (MMP) dan Kader Konservasi merupakan bentuk-bentuk partisipasi masyarakat Desa Komodo dalam konservasi lingkungan di Pulau Komodo. MMP dan Kader Konservasi diberikan pembinaan secara berkala mengenai konservasi lingkungan oleh Balai Taman Nasional Komodo (BTNK) 
setiap tahunnya. Pembinaan yang diberikan oleh BTNK tersebut menambah pengetahuan masyarakat mengenai lingkungan. Hal tersebut dilakukan agar dengan pengetahuan yang dimiliki, MMP atau Kader Konservasi dapat memberikan pengaruh positif mengenai lingkungan terhadap masyarakat lain di sekitarnya.

McIntosh dan Goeldner (1986) menekankan pentingnya keterlibatan masyarakat yang lebih luas agar mencapai lima tujuan pengembangan pariwisata, salah satu diantaranya ialah pengembangan infrastruktur dan penyediaan fasilitas-fasilitas rekreasi bagi penduduk dan pengunjung. Keterlibatan masyarakat Desa Komodo dalam pengembangan ekowisata di Pulau Komodo memberikan dampak positif terhadap lingkungan, yaitu dengan adanya pengembangan infrastruktur di Desa Komodo. Berbagai infrastruktur desa seperti jalan setapak maupun Mandi Cuci Kakus (MCK) yang melibatkan warga Desa Komodo dalam pengerjaannya, saat ini sudah memberikan berbagai manfaat yang bisa dinikmati oleh warga Desa Komodo. Selain itu, pengembangan infrastruktur Desa Komodo yang melibatkan masyarakat memberikan kesan lingkungan Desa Komodo yang tertata dan rapih.

Partisipasi masyarakat Desa Komodo berdampak positif terhadap sosial budaya masyarakat Desa Komodo. Salah satu indikator dampak positif partisipasi masyarakat, dapat dilihat dengan adanya peningkatan kualitas Sumber Daya Manusia (SDM) masyarakat Desa Komodo. SDM adalah kemampuan terpadu dari daya pikir dan daya fisik yang dimiliki individu (Hasibuan, 2003:244). Dari definisi tersebut dapat dijelaskan bahwa SDM merupakan potensi yang terkandung di dalam diri seseorang. Potensi yang dimiliki dalam diri seseorang dapat dikembangkan dengan tujuan untuk meningkatkan kualitas SDM. Terdapat berbagai upaya untuk meningkatkan kualitas SDM, diantaranya adalah dengan memberikan pelatihan, pendidikan serta pembinaan. Mayoritas penduduk Desa Komodo berpendidikan rendah. Data penduduk Desa Komodo berdasarkan pendidikan pada tahun 2014 menunjukkan bahwa, terdapat 1.570 dari total 1.727 masyarakat Desa Komodo belum/tidak menyelesaikan pendidikan dasar 9 (sembilan) tahun. Rendahnya tingkat pendidikan masyarakat Desa Komodo tersebut berdampak pada rendahnya kualitas SDM masyarakat Desa Komodo. Namun, berbagai program pengembangan kualitas SDM yang dilakukan oleh stakeholders, seperti Yayasan Komodo Kita maupun Balai Taman Nasional Komodo banyak membantu meningkatkan kualitas SDM masyarakat Desa Komodo. Masyarakat Desa Komodo yang berpartisipasi dalam pengembangan ekowisata mendapatkan berbagai program pengembangan kualitas SDM, seperti pengajaran Bahasa Inggris, pembinaan generasi muda, pelatihan mengukir patung, pelatihan guiding, training hospitality dan pelatihan pembuatan souvenir. Dengan mengikuti 
program pengembangan kualitas SDM tersebut, artinya terjadi peningkatan kualitas SDM masyarakat Desa Komodo.

Selain berdampak pada peningkatan kualitas sumber daya manusia masyarakat Desa Komodo, dampak positif lain dari partisipasi masyarakat Desa Komodo dalam pengembangan ekowisata terindikasi dengan adanya peralihan mata pencaharian dari sektor kelautan ke sektor ekowisata. Masyarakat dalam kawasan Taman Nasional Komodo (TNK) umumnya maupun di Desa Komodo khususnya adalah masyarakat dengan kebudayaan yang dibangun dari aspek kelautan, di mana laut merupakan sumberdaya alam tempat menggantungkan hidup.

Namun, seiring dengan berkembangnya kepariwisataan di Pulau Komodo, masyarakat Desa Komodo secara perlahan mengalami peralihan mata pencaharian dari sektor kelautan ke sektor ekowisata. Masyarakat Desa Komodo yang awalnya merupakan nelayan tradisional, menyadari bahwa dengan adanya kegiatan ekowisata di Pulau Komodo berpotensi memberikan manfaat bagi mereka sendiri. Hal tersebut mendorong mereka untuk berpartisipasi di sektor ekowisata. Peralihan mata pencaharian ini berdampak secara tidak langsung terhadap terpeliharanya ekosistem lautan di sekitar Pulau Komodo. Dengan semakin berkurangnya jumlah nelayan yang berasal dari Desa Komodo, maka semakin kecil pula potensi kerusakan yang dapat ditimbulkan dari aktivitas penangkapan ikan.

\section{Simpulan dan Saran}

Penelitian ini telah mengemukakan tiga aspek yang berkaitan dengan partisipasi masyarakat Desa Komodo dalam pengembangan ekowisata di Pulau Komodo. Ketiga aspek tersebut adalah bentuk-bentuk partisipasi masyarakat Desa Komodo, faktor-faktor yang mempengaruhi partisipasi masyarakat Desa Komodo, dan dampak positif partisipasi masyarakat Desa Komodo dalam pengembangan ekowisata di Pulau Komodo.

Bentuk-bentuk partisipasi masyarakat Desa Komodo dalam pengembangan ekowisata di Pulau Komodo, antara lain partisipasi masyarakat Desa Komodo dalam Program Desa Wisata Komodo BNI, yaitu dengan cara memberikan usulan, dan sebagai pekerja proyek pembangunan infrastruktur desa. Partisipasi masyarakat Desa Komodo dalam usaha ekowisata, yaitu sebagai pengerajin patung komodo, menjual cenderamata, pemandu wisata alam (naturalist guide), mengelola homestay, dan menyewakan perahu motor. Partisipasi masyarakat Desa Komodo dalam konservasi, yaitu dengan terlibat dalam kelompok Masyarakat Mitra Polisi Kehutanan dan Kader Konservasi.

Faktor-faktor yang mempengaruhi partisipasi masyarakat Desa Komodo dalam pengembangan ekowisata di Pulau Komodo terbagi ke dalam dua jenis, yaitu faktor-faktor yang mendorong dan faktor-faktor yang menghambat. 
Faktor-faktor yang mendorong, di antaranya adalah adanya dukungan dari stakeholders, motivasi masyarakat untuk memperoleh manfaat ekonomi dari ekowisata, dan motivasi masyarakat untuk menjaga lingkungan. Sedangkan, faktor-faktor yang menghambat adalah terbatasnya anggaran, sikap apatis dan kesadaran masyarakat yang rendah, fluktuasi kunjungan wisatawan, serta kesulitan memasarkan produk ekowisata.

Partisipasi masyarakat Desa komodo dalam pengembangan ekowisata di Pulau Komodo memberikan dampak positif yang meliputi sektor ekonomi, lingkungan, serta sosial budaya. Dampak positif partisipasi masyarakat Desa Komodo dalam pengembangan ekowisata terhadap sektor ekonomi, terindikasi dengan adanya pendapatan dari usaha ekowisata serta terbukanya peluang kerja baru bagi masyarakat Desa Komodo. Dampak positif terhadap lingkungan, yaitu terpeliharanya ekosistem darat dan laut, menambah pengetahuan masyarakat mengenai lingkungan, dan pengembangan infrastruktur desa. Dampak positif partisipasi masyarakat Desa Komodo terhadap sosial budaya, terindikasi dengan adanya peningkatan kualitas sumber daya manusia masyarakat dan terjadinya peralihan mata pencaharian masyarakat dari sektor kelautan ke sektor ekowisata.

Partisipasi masyarakat Desa Komodo dalam pengembangan ekowisata di Pulau Komodo perlu didorong dan ditingkatkan. Perlu adanya pemerataan pengembangan kualitas sumber daya manusia masyarakat Desa Komodo yang dilakukan secara berkala, serta pemenuhan ketersediaan bahan baku bagi para pengerajin. Peran serta stakeholders melalui pendampingan, pembinaan, serta bantuan permodalan maupun bantuan peralatan dalam menunjang partisipasi masyarakat, agar dilakukan secaraberkesinambungan.

\section{Ucapan Terima Kasih}

Penulis mengucapkan terima kasih kepada Ketua Program Studi Magister Kajian Pariwisata Program Pascasarjana Universitas Udayana Prof. Dr. I Nyoman Darma Putra, M. Litt., kepada Pembimbing I yaitu Prof. Dr. I Nyoman Sirtha, SH., MS dan Pembimbing II yaitu Dr. Ir. Syamsul Alam Paturusi, MSP. Anggota Penguji Dr. Ida Bagus Pujaastawa, MA., Dr. I Nyoman Madiun, M.Sc., serta Dr. Ir. AAP. Agung Suryawan Wiranatha, M.Sc. Seluruh staf pengajar Program Studi Magister Kajian Pariwisata Program Pascasarjana Universitas Udayana beserta staf administrasi atas segala bantuannya. Penulis juga mengucapkan terima kasih kepada Ibu Dewi dan Bapak Hermanto dari Balai Taman Nasional Komodo, seluruh narasumber serta bagi berbagai pihak yang telah membantu penulis dalam melakukan penelitian ini. 


\section{Daftar Pustaka}

Aref, Fariborz dan Marof, B. R. 2008. "Tourism and Community Capacity Building: A Literature Review”. Pakistan Journal of Social Science, pp. 806-812.

Baksh, R; Soemarno; Hakim, L; Nugroho, I. 2012."Community Participation in the Development of Ecotourism: A Case Study in Tambaksari Village, East Java Indonesia”. Journal of Basic and Applied Scientific Research, Vol. 2; No. 12; pp.12432-12437.

Balai Taman Nasional Komodo. 2010. Rencana Strategis Balai Taman Nasional Komodo 2010 - 2014. Labuan Bajo: Balai Taman Nasional Komodo.

Bansal, S. P. dan Kumar, Jaswinder. 2011. "Ecotourism for Community Development: A Stakeholder's Perspective in Great Himalayan National Park”. International Journal of Social Ecology and Sustainable Development, 2(2), pp. 31-40.

Barnard, Timothy P. 2011. "Protecting the Dragon: Dutch Attempts at Limiting Access to Komodo Lizards In The 1920s and 1930s”. Indonesia; Oct. 2011; 92; ProQuest; pp. 97-123.

Direktorat Jenderal Cipta Karya. 1998. Kamus Tata Ruang. Jakarta: Departemen Pekerjaan Umum.

Eagles, P. F. J. and Martens, J. 1997. "Wilderness Tourism and Forestry: The Possible Dream in Algonquin Provincial Park”. Journal of Applied Recreation Research, 22 (1): pp. 79-97.

Ezebilo, Eugene E.; Mattsson, Leif; Afolami, Carolyn A. 2010. " Economic Value of Ecotourism to Local Communities in the Nigerian Rainforest Zone”. Journal of Sustainable Development, Vol. 3, Issue 1, pp. 51-6o.

Hadi, S. P. 2005. Dimensi Lingkungan Perencanaan Pembangunan. Yogyakarta: Gadjah Mada University Press.

Hasibuan, Malayu S. P. 2003. Manajemen Sumber Daya Manusia. Jakarta: Bumi Aksara.

Hill, Jennifer L and Hill, Ross A. 2011. "Ecotourism in Amazonian Peru: Uniting Tourism, Conservation and Community Development”. Geography, Vol. 96, Part 2, pp.75-85.

Iriyono, S; Syari'fudin, M. I; Kurniawan, M; Adnan, A; Indriasari, D; Buaithi, A; Margaretha P. N. 2013. The Assessment of Komodo National Park's Role in the Economics of West Manggarai Regency Nusa Tenggara Timur Province (Development of Ecotourism Utilization Aspect Case Study). Labuan Bajo: Komodo National Park Office.

Kecamatan Komodo. 2014. Data Penduduk Desa Komodo Berdasarkan Pendidikan. Labuan Bajo: Kecamatan Komodo.

Lama, Minki. 2013. "Community Homestay Programmes as a Form of Sustainable Tourism Development in Nepal” (tesis). Centria University of Applied Sciences: Degree Programme in Tourism.

McIntosh, R. W. \& Goeldner, C. R. 1986. Tourism: Principles, practices and philosophies. New York: Wiley. 
Nurdin, M. 2008. "Aspek Finansial Pengembangan Pariwisata di Kawasan Taman Nasional”. UNAIR: FISIP. Jurnal Masyarakat Kebudayaan dan Politik, Vol. 21, No. 1, pp. 43-49.

Okazaki, Etsuko. 2008. "A Community-Based Tourism Model: Its Conception and Use”. Journal of Sustainable Tourism, Vol. 16, No. 5, pp. 511-529.

Peraturan Menteri Kehutanan Republik Indonesia, Nomor : P.56/Menhut-II/2014, tentang Masyarakat Mitra Polisi Kehutanan.

Pitana, I Gde dan Diarta, I. K. S. 2009. Pengantar Ilmu Pariwisata. Yogyakarta: Penerbit ANDI.

Pretty, Jules N. 1995. "Participatory Learning for Sustainable Agriculture”. World Development, Vol. 23, No. 8, pp. 1247-1263.

Putra, I Nyoman Darma dan Pitana, I Gde. 2010. Pariwisata Pro-Rakyat: Meretas Jalan Mengentaskan Kemiskinan di Indonesia. Jakarta: Kementrian Kebudayaan dan Pariwisata Republik Indonesia.

Ross, Sheryl and Wall, Geoffrey. 1999. "Ecotourism: Towards Congruence

Between Theory and Practice”. Tourism Management, 20(1): pp. 123-132.

Santosa, M. A dan Heroepoetri, Arimbi. 2005. Peran Serta Masyarakat dalam

Pengelolaan Lingkungan. Available from http: //www.pacific.net.id.

Sastropoetro, Santoso. 1988. Partisipasi, Komunikasi, Persuasi dan Disiplin dalam Pembangunan Nasional. Bandung: Penerbit Alumni.

Scheyvens, R. 2002. Tourism for Development: Empowering Communities. London: Prentice Hall.

Slamet, Y. 1994. Pembangunan Masyarakat Berwawasan Partisipasi. Surakarta: Sebelas Maret University Press.

Soetrisno, Loekman. 1995. Menuju Masyarakat Partisipatif. Yogyakarta: Kanisius.

Stem, C. J; Lassoie, J. P; Lee, D. R; Deshler, D. D; dan Schelhas, J .W. 2003. "Community Participation in Ecotourism Benefits: The Link to Conservation Practices and Perspectives”. Society and Natural Resources, Vol. 16, Issue 5, pp. 387-413.

Suciati. 2006. "Partisipasi Masyarakat dalam Penyusunan Rencana Umum Tata Ruang Kota Pati” (tesis). Semarang: Universitas Diponegoro.

Tosun, Cevat. 2000. "Limits to Community Participation in the Tourism Development Process in Developing Countries”. Tourism Management, 21, pp. 613-633.

Walpole, M. J dan Goodwin, H. J. 2001. "Local Attitudes towards Conservation and Tourism around Komodo National Park, Indonesia”. Environmental Conservation, 28 (2): pp. 160-166.

Walpole, M. J dan Leader-Williams, N. 2002. "Tourism and Flagship Species in Conservation”. Biodiversity and Conservation, 11: pp. 543-547.

Wang, Hongshu danTong, Min. 2009. Research on Community Participation in Environmental Management of Ecotourism. International Journal of Business and Management, Vol. 4, No.3, pp. 131-135. Available from : http://www. ccsenet.org/journal/index.php/ijbm/article/viewFile/281/256 
Wang, Y.; Pfister, R.; dan Morais, D. 2006. "Residents' Attitudes Toward Tourism Development: A Case Study Of Washington, Nc”. Northeastern Recreation Research Symposium, GTR-NRS-P-14, pp. 411-418.

\section{Website :}

http://www.valadoo.com/packages/sites/default/files/imagecache/ valadoo_780372/131028-o5-flores-gili\%2olawa_o.jpg

\section{Profil Penulis}

Rafael Modestus Ziku, SS adalah mahasiswa Program Studi Magister Kajian Pariwisata di Universita Udayana. Menyelesaikan Program Strata-1 Sastra Inggris di Sekolah Tinggi Ilmu Bahasa Asing (STIBA) Universitas Mahasaraswati Denpasar pada tahun 2012. Pernah bekerja sebagai staf reservasi pada sebuah hotel di Labuan Bajo, Manggarai Barat. 